\title{
СЕМАНТИКА НАРОДНОЇ ІКОНИ В КОНТЕКСТІ МЕТОДОЛОГІЧНИХ ЗАСАД СТРУКТУРАЛІЗМУ
}

Амбівалентність постмодерної соціокультурної ситуації, з одного боку, виявляється у конституюванні принципу нелінійності та поліфонії смислів, а з іншого, - зумовлює актуалізацію досліджень, пов'язаних з відтворенням тих символіко-культурних констант, що лежать в основі національної ідентичності. Деструкція як засаднича характеристика сучасного соціокультурного буття співвідноситься 3 відродженням інтересу до етнокультурних спільнот та новим спалахом національних рухів. 3 культурологічної точки зору, особливу увагу привертає залучення до скарбниці національної спадщини тих надбань, що історично сформувалися поза структурованим простором міської культури. Провідне місце серед них посідає народний живопис, зокрема народна ікона, яка разом з фольклором залишається одним із найголовніших засобів вивчення особливостей народного світорозуміння як органічної частини національного світогляду.

Актуалізація досліджень, присвячених вивченню народної ікони, не супроводжується таким самим інтересом дослідників до пошуку тих методологічних засад, які відкриють можливість ії комплексного вивчення. Тож сьогодні ми маємо лише кілька мистецтвознавчих розвідок, присвячених народній іконі. Серед них - праці В.Отковича, О.Найдена, О.Осадчої, П.Жолтовського, В.Костюка, Д.Степовика та ін. Ці дослідники, як правило, зосереджують свою увагу на розкритті динаміки ідейної програми та художніх прийомів народної ікони. Втім, вони повністю нівелюють той факт, що народна ікона може розглядатися як своєрідний текст, що виявляє ті глибинні механізми мислення, які й визначають несвідому, а тому й найбільш сталу, структуру етнічної культури. Надзвичайно плідним щодо цього стає метод структурного аналізу К. Леві-Стросса. Дослідник у праці «Первісне мислення» доводив, що міф та мова фундаментальні характеристики колективної пси-хіки, що мають певну незмінну структуру, яка й забезпечує сталість соціальних зв'язків. Поширення структуралістської методології в соціогуманітарному дискурсі другої половини XX - початку XXI ст. дає підстави 
припускати, що вона може стати ефективною й при дослідженні народної ікони, яка конституюється як знак, що набуває певного смислового значення в контексті певної події.

Отже, метою статті є розкриття семантичного значення народної ікони крізь призму структуралістської методологічної програми К. Леві-Стросса.

Підкреслюючи доцільність застосування структуралістської методології у вивченні народної ікони, ми повністю дистанціюємося від тих підходів, що свідомо чи несвідомо вбачають у ній елементи формалізму. Представники останнього, як відомо, зосереджуються переважно на протиставленні конкретного та абстрактного, змісту та форми, надаючи пріоритету останнім. Зміст мистецького формалізму досить красномовно розкрив М. Горький. «У літературі, - пише він, - зайва орнаментика і деталізація неминуче призводять до затьмарення змісту фактів і образів... Формалізм як «манера», як «літературний прийом» найчастіше служить для прикриття порожнечі чи злиднів душі. Людині хочеться говорити 3 людьми, але сказати їй нічого, і виснажливо, багатослівно, хоча іноді й красиво, добре підібраними словами, вона говорить про все, що бачить, але чого не може, не хоче або боїться зрозуміти. Формалізмом користуються зі страху перед простим, ясним, а іноді і грубим словом, боячись відповідальності за це слово. Деякі автори користуються формалізмом як засобом одягнути свої думки так, щоб не відразу було зрозуміло їх потворно вороже ставлення до дійсності, їх намір спотворити зміст фактів і явищ» [2].

Незважаючи на те, що запропоноване М.Горьким тлумачення мистецького формалізму досить повно розкриває його своєрідність, все ж воно залишається значно спрощеним оскільки не дає можливості побачити тієї відкритості мистецького твору, яку він отримує в різних контекстах та середовищах. Крім того, не варто забувати, що представники формалізму головну увагу приділяють розкриттю сутності речей, виявленню їх «значущої форми», а не зовнішньої подібності. Саме таким, на думку К. Малевича, була «барвиста взірність» українського селянського мистецтва, що було повністю підпорядковане тому космологічно-міфологічному простору, в якому жила окрема людина та спільнота. Органічною частиною цього мистецтва став народний іконопис, який, на думку митця, може розглядатися як «форма найвищої культури селянського мистецтва». «Я зрозумів селян - писав К.Малевич - через ікону, зрозумів їхню подобу 
не як святих, а як простих людей... Я собі чітко уявив усю лінію від великого іконописного мистецтва до коників і півників, розмальованих стін, порядок строїв як лінію селянського мистецтва. Іконописці, сягнувши великої майстерності в техніці, надавали перевагу антианатомічній правді... Колір і форму вони творили на суто емоційному сприйнятті теми» [Цит. за: 7, 40].

Зауваження К. Малевича щодо барвистості та антианатомічності народної ікони підтверджують представлені у деяких приватних колекціях та музейних залах народні ікони. На відміну від професійної ікони, народна ікона спрямована передати не стільки зовнішній вигляд, скільки зміст візуального образу, який передавався за допомогою регіонально усталеної кольорової палітри. Однак існування виразних регіональних відмінностей кольорової гами народної ікони дає підстави вважати, що вона не була настільки емоційно зумовлена, наскільки це хотів побачити К. Малевич. Більше того, як свідчать робота О.Косміної «Традиційне вбрання українців», К.Малевич дещо перебільшує, стверджуючи, що «селянські одежі... барвисті, візерунчасті, що кожен шив собі таку вдяганку, яку хотів» [Цит. за: 7, 36]. Дистанціюючись від ідеї барвистості селянського одягу, особливо буденного, все ж вважаємо за доцільне спинитися хоч кількома словами на регіональних особливостях народного одягу. Адже, як стверджує О.Косміна, у його своєрідності знайшли своє відображення «краса та щедрість природи чотирьох макрорегіонів України» $[4,2]$. Це, в свою чергу, підтверджує глибоку підпорядкованість селянського життя та побуту тому природному середовищу, в якому воно реалізувалося. 3 іншого боку, одяг служив засобом виокремлення 3 природного середовища шляхом утвердження соціального статусу його власника. «Традиційний одяг, - підкреслює О.Косміна, - чітко розмежовує такі поняття, як свій/чужий, багатий/бідний, дівчина/жінка» [4, 2].

Іншими словами, незважаючи на позірну схожість народної ікони з тими художніми творами, які надають перевагу формі, залишаючи зміст відкритим для інтерпретації, все ж ці види мистецтва не можна споріднювати. Адже головною основою формалізму стала «свобода від» історичного контексту, життєвих обставин чи причин творення певного мистецького твору. В свою чергу, народна ікона була органічною частиною підпорядкованого природному процесу культурного простору селянського життя. Народна ікона не була самоцінною, вона набувала онтологічного статусу та семантичного 
наповнення лише в тому випадку, коли була включена в світоглядний та побутовий контекст життя людини та родини, які перебували у незмінному циклічному коловороті природного процесу. Не можна забувати й того, що народна ікона поставала не просто нагадуванням про первообраз, іконний образ, набуваючи дійсного онтологічного статусу, оживав й посідав окреме місце в ієрархізованому та сакралізованому життєвому просторі українського селянина.

Що ж до підкресленої К. Малевичем принципової антианатомічності народної ікони, то, на наш погляд, вона була зумовлена не стільки особливостями емоційного сприйняття божественного, скільки глибоким вкоріненням архаїчних уявлень. Як відомо, в межах останніх панувало переконання, 3 одного боку, що все існуюче володіє мовою, тобто виявляється за допомогою знаку (слова, образу), а з іншого, - що знак (слово, образ) було своєрідною копією того, що або кого воно позначає $[3,11]$. Знак (слово, образ) не тільки володіє властивостями того, що воно позначає, а й може виступати замінником того, що (кого) воно позначає. Саме на тлі цих архаїчних уявлень сформувалася давня традиція приховувати справжні імена («воймя» Г. Лозко) від сторонніх і користуватися в буденному житті змінними, відповідно до віку та ситуації, прізвиськами. «Ім'я як знак, - зауважує О.Донських, - поставало тією найбільш істотною частиною предмета, без якої він не існує» [3, 17]. Аналогічне значення, на наш погляд, мав і образ. Адже, як зауважує О.Найден, спираючись на роботи В.Білецької, творити «зображення конкретної людини... - створювати живу реальність, діяльну та чуттєву модель цієї людини» [7, 57]. Зважаючи на це, малюнок в народному середовищі сприймався як щось живе й тим самим уможливлював магічні дії.

Глибока вкоріненість архаїчних уявлень в селянському світогляді зумовила досить обережне ставлення до портрета та дозволу себе малювати. Врешті-решт, вважає О.Найден, в українському народному середовищі досить довго утримувалася заборона малювати портрети з живих осіб $[7,58]$. Аналогічних висновків доходить і К.Широцький у статті «Дещо про давні портрети». Дослідник доводить існування звичаю, «за котрим боялися писати портрет людини за іiі життя; через те з живої натури писалася лише фігура одежа, руки, аксесуари, а лице дописувалось тоді вже, коли чоловік умирав - теж 3 натури або по пам'яті - може не тим вже й майстром» [Цит. за: 7, 58]. 
На думку О.Найдена, застороги й зауваження, зроблені щодо портретного живопису, стосувалися й ікони та власного зображення божественних ликів, святих, які мали «збігатися 3 духовним образом» $[7,58]$. Зрештою, ікони «спочатку не зовсім корелювалися 3 семантичним ієрархізованим природно-космологічним простором інтер'єром селянського житла, вносячи в нього певний дисонанс» [7, 58]. Подолати останній можна було за допомогою орнаментованого рушника, який «виконує роль посередника між нею [іконою - О.Б.] та ієрархізованим простором сільської хати. Водночас (а може, й насамперед), - підкреслює О.Найден, - рушник є естетичним посередником між стіною хати та іконою» $[7,59]$.

Дистанціюючись від докладного аналізу однобокого тлумачення призначення орнаментованого рушника в обрядовій культурі українського народу та оціночних характеристик висновків, зроблених О.Найденом, звернімо увагу лише на зауваження дослідника про те, що народна ікона від самого початку була повністю позбавлена реалістичності. Підкреслюючи цей факт, О.Найден цілком ігнорує той факт, що народна ікона стала органічною частиною сільської хати саме в той момент, коли іiі залишили такі самі схематичноформальні язичницькі ідоли, форма (ідея - за термінологією Платона) яких існує лише завдяки їі образному втіленню. Іншими словами, аналогічно до того, як заборонено було писати реалістичний портрет людини за ії земного життя (оскільки це приведе до існування своєрідного двійника), відтворюючи в іiі посмертному лиці лише ті сутнісні риси людини, які найбільш закарбувалися в пам'яті, писалися і іконні лики, які, не потребуючи реалістичності, були спрямовані передати зміст божественного. Показово, що останнє завжди було включеним у світоглядно-міфологічний контекст єдності мікро- та макрокосмосу, внаслідок чого народна ікона, відображаючи, з одного боку, навколишній світ того «дикого поля» (Х.Ортега-і-Гассет), в якому жила людина (в даному випадку привертають увагу квіти та дерева, які зустрічаються на більшості народних ікон), а з іншого, - будучи включеною в сакралізований простір селянського дому, несла в собі риси і природного середовища, і родинної організації. Крім того, посівши місце давніх ідолів, народна ікона повністю перебрала на себе їх функціональне значення, відобразивши щедрість природи, яка забезпечує благополуччя родини, опіку роду над особистістю та циклічний коловорот природного процесу. Усі ці ідеї забезпечували незламну 
віру людини в безсмертя, а відтак - відзначалися щирістю та доброзичливістю, які мали нести в собі і природа, і спільнота.

Отже, маємо всі підстави стверджувати, що в народній свідомості Бог (божественне) існував завдяки тому, що був зображеним, позначеним та включеним в ієрархізований простір селянського життя. 3 іншого боку, зображення божественного несло в собі відображення того природного світу, в якому жила спільнота. В свою чергу, підпорядкованість народної ікони ієрархізованому та сакралізованому життєвому простору українського селянина $є$ вкрай важливою для підкреслення методологічної нездатності формалізму виявити ії дійсне значення та зміст. В народній іконі нема протиставлення конкретного та абстрактного, іiї своєрідність полягає в тому, що в ній немає змісту, відірваного від форми, і форми відірваної від змісту, а тому маємо всі підстави припускати, що структуралістська методологічна програма, спрямована на виявлення ії незмінної структури, «змісту, що вкладений в логічну форму» (К.ЛевіСтросс), може мати високий евристичний потенціал.

Більше того, користуючись методологічними засадами В.Проппа та К.Леві-Стросса, ми дійшли висновку, що є всі підстави вважати народну ікону образним вираженням народного міфу $[5,19]$. При цьому ми цілком свідомі того, що «відмінність між цими двома жанрами... виявляється об'єктивно за допомогою розпізнавальних термінів». Безперечно, ці «відмінності становлять великий інтерес для етнографа, однак навряд чи вони засновані на природі речей» $[5,17]$. Крім того, не викликає жодних сумнівів і підкреслений вище космологічний, метафізичний та природний характер народної ікони. Причому, виділення первинної незмінної структури культурного простору можливе тільки на основі народного міфу та, відповідно, ії образного втілення - народної ікони. Це зумовлено тим, що сільський культурний простір, будучи органічно включеним у природний процес, мало піддається цивілізаційним змінам. Як засвідчує українська історія XX ст., змінити, викорінити осердя культурного простору сільської спільноти можна, лише зруйнувавши онтологічно-семантичний простір ії буття, що частково відбулося через насильницьку колективізацію.

Повертаючись до особливостей методу структурного аналізу, зауважимо, що його реалізація, на відміну від формалізму, який реалізується лише поза історичним контекстом, здійснюється в межах контексту. К.Леві-Стросс, досліджуючи структуру первісного 
мислення, підкреслює, що змінність змісту міфу не можна розглядати як випадковість, оскільки вона завжди зумовлена контекстом. Фактично, коли йдеться про народну ікону, то варто брати до уваги, що ії тлумачення значною мірою залежало від того, де вона була розміщена й яким чином включена до символічного простору житла. Наприклад, коли йдеться про покуть - священне місце поховання предків, то народна ікона набуває власного семантичного значення відповідно до того, який зміст в даному контексті має покуть. Іншими словами, «зміст черпає реальність із структури, а те, що називають формою, є «включення у структуру» локальних структур, з яких складається зміст» $[5,23]$.

Поряд зі сказаним, К. Леві-Стросс зауважує також, що діалектику змісту і форми можна простежити і крізь призму історизму і «позаісторизмом». В такому випадку, зауважує мислитель, «порядок хронологічного слідування розчиняється у позачасовій матричній структурі, форма якої дійсно постійна; перестановка функцій - суть не що інше, як один з видів заміщення (в вертикальних шпальтах або в їх фрагментах)» $[5,28]$. Це, в свою чергу, означає, що у міфах (як і в казках) немає нічого випадкового, вони складаються 3 міфем, що постали результатом бінарних та тернарних опозицій, які набувають смислу не apriori, a posteriory (завдяки досвіду). Фактично, йдеться про те, що в основі міфем лежить структура, що актуалізується на двох рівнях: по-перше, вона має власне стале значення, а по-друге, актуалізується як один із елементів цілісної композиції.

Застосувавши окреслений нами метод до аналізу народної ікони, визнаємо, що кожен з ії елементів може існувати окремо, а може бути представлений «гіперструктурно», тобто у цілісній композиції. Ікона, таким чином, постає своєрідною метамовою, яка, 3 одного боку, має в собі незмінну цілісну структуру, а з іншого, передбачає цілу систему смислів та форм, що актуалізуються лише у певному просторовому контексті. Знаки народної ікони постають своєрідними засобами для побудови цілісної понятійної системи, яка на рівні міфологічного, раціонально нерозчленованого мислення виявляється через призму бінарних опозицій, які актуалізуються на двох рівнях: у відношенні до природи, і у відношенні до культури $[5,31]$. Причому, проблема лексики чи символу відіграє в даному випадку вторинне значення, адже вона тісно пов'язана з історичним та етнографічним контекстом певного міфу. 
Отже, розглядаючи структуру, з одного боку, як абстрактну модель, що лежить в основі народного міфу, а з іншого - як сукупність інваріантних відношень, К. Леві-Стросс намагається віднайти ті «ментальні структури», які визначають своєрідність певної культури та нівелюють відносно вільну діяльність людського «Я». Такі ментальні структури найбільш чітко проявляються в міфі, чистота якого найбільш повно збережена у «сільському середовищі... якого не торкнулася цивілізація» $[5,20]$.

Застосовуючи методологічні зауваги К. Леві-Стросса до аналізу української народної ікони, яка, на наш погляд, є одним із кращих візуальних виявів народного міфу, цілком ймовірно віднайти ті, найбільш стійкі структурні компоненти, які визначили своєрідність не тільки народної ікони, а й української культури в цілому. Реалізація цієї мети неможлива поза просторовим контекстом слов'янської міфології, де одним із найголовніших символів виступало Дерево Життя. Воно найбільш повно втілювало в собі цілісну систему космологічних уявлень слов'ян, які розглядали світ як органічну єдність трьох світів (або рівнів): Прави (світу вічного, божественного, небесного), Яви (світу земного, проявленого, людського) та Нави (світу померлих предків, як своїх, так і чужих). Сдність цих світів забезпечувалася вічним коловоротом життя, що актуалізувався через бінарні опозиції народження та смерті. Відповідно до цих уявлень вибудовувалася ієрархія язичницьких божеств. Род поставав символом вічності, Сонце (Даждьбог) - уособлювало вічний коловорот життя, Макош забезпечувала благополуччя земного життя й разом з тим виступала своєрідним зв'язковим небесного та земного світів.

Досить чітко представлені у слов'янській міфології бінарні опозиції життя та смерті, земного та небесного, вічного та змінного згодом проявилися і у християнізованій народній культурі. Адже, будучи зумовленою природним простором, консервативність народної культури не давала можливості для проникнення принципово нових ідей. Відповідно, давні міфологічні уявлення не могли повністю відобразитися в докорінно новому контексті. Перше, що в цьому розумінні, привертає увагу та визначає, - це концепт триєдності Бога, або головна ідея християнства. Вона актуалізується крізь призму трьох іпостасей Бога: Бог-Отець - вічне та істинне буття (Права), Бог-Син - появлений світ, земне буття (Ява), і Дух Святий, який, відповідно до богословського віровчення, є Особою, 
яка: «А коли прийде Він, Той Дух правди, Він вас попровадить до цілої правди, бо не буде казати Сам від Себе, а що тільки почує, казатиме, і що має настати, - звістить вам [виділення - О.Б.]» (Від Івана 16:13). Дух Святий обдаровує людей різними благами відповідно до власної волі: «Одному бо Духом дається слово мудрости, а другому слово знання тим же Духом, а іншому віра тим же Духом, а іншому дари вздоровлення тим же Духом,а іншому роблення чуд, а іншому пророкування, а іншому розпізнавання духів, а тому різні мови, а іншому вияснення мов. А все оце чинить один і той Самий Дух, уділяючи кожному осібно, як Він хоче» (1 до Коринтян 12:8-11). Іншими словами, Дух Святий залишає за собою те функціональне значення, що мали померлі предки, які з часом перетворилися на «могутніх оборонців своєї родини й сильно допомагали їм у житті» [6, 233].

Проводячи паралель між світом Нави, культом предків та концептом Духу Святого, все ж не варто ігнорувати того, що Нава від самого початку визначалася виразною бінарною опозицією свій/чужий. Опікати людину та спільноту могли тільки духи рідних предків, в свою чергу, чужі померлі предки були ворожими й могли зашкодити людині. Сформоване ще в міфологічній свідомості амбівалентне ставлення до смерті та померлих не могло не відобразитися й у християнізованій культурі, яка розглядала смерть, з одного боку, як можливість досягнення Царства Божого, а з іншого, - як результат гріхопадіння, яке несло з собою біль, страждання та ворожнечу. Все це було надзвичайно чужим семантичному простору української хати, а тому образів Страшного Суду тут ніколи не розміщували. Негативне значення смерті належало до простору «чужого», а тому від нього треба було захиститися та відсторонитися.

Космологічні уявлення українського простонароддя найбільш повно виявилися в образах Саваофа. Майже на усіх народних іконах Бог-Отець зображений разом з немовлям на хресті та голубом. Ймовірно, загальна концепція підпорядкована первинній структурі космологічного народного міфу - ідеї вічного коловороту життя, яке йде від юності (Нового року, 21-22 березня, Христос у вигляді немовляти) до зрілості (Купало, 21-22 червня, Бог-Отець). Ідею вічного коловороту уособлює в собі хрест, який в язичницькій культурі є солярним знаком. Ікона Саваофа має в собі ідею єдності земного (Христос) та небесного (Саваоф), яку відображає голуб як символ нерозривної єдності $[1,20]$. 
Поряд 3 образами Саваофа привертають увагу й найбільш поширені на Україні народні ікони «Богородиця з немовлям». На наш погляд, саме в цих образах найбільш повно представлені не тільки основні слов'янські міфеми, а й загальна структура міфологічного мислення. Адже, розклавши цілісний образ «Богородиця 3 немовлям» на різні рівні, отримуємо наступні бінарні опозиції: Богородиця - жінка, зріла, земна, Христос-немовля - чоловік, юність, небесний. Незважаючи на те, що кожен із цих образів у різних контекстах може набувати різного значення, однак у цілісній композиції образу вони постають вічною та незмінною єдністю земного та небесного життя. Досить виразно представлена в даному образі і життєдайна природа землі (Бого-родиця), врожай (Христос) якої перебуває у вічному коловороті циклічного народження (щорічне Різдво).

Підкреслену ідею єдності бінарних опозицій, у відношенні до природи (єдність життя та смерті, неба та землі, вічного та тлінного, та щодо культури: жіночого та чоловічого, молодості та старості тощо) знаходимо в усіх народних іконах. При цьому привертає увагу той факт, що всі домашні народні ікони, несучи в собі ідею смерті, були повністю позбавлені ії негативного змістового навантаження. Смерть, постаючи природною характеристикою, розглядалася як запорука народження, а не як запорука ущербності та неповноцінності людського життя.

Отже, позірна спорідненість народної ікони з формалізмом не дає підстав констатувати їхню ідейну спорідненість. Тимчасом як формалізм надає пріоритету формі, що виключена з контексту, народна ікона постає явищем цілком підпорядкованим семантичному простору селянського житла та зовнішньому щодо нього космологічному простору. На відміну від формалізму, який постає результатом емоційного переживання дійсності, народна ікона - це, з одного боку, результат історичного розвитку народних уявлень та переконань (народного міфу), а з іншого - візуальний вияв інваріантної структури народного мислення. 


\section{ЛІТЕРАТУРА}

1. Богомолець О. Домашні ікони центральної України (За матеріалами виставки «Домашні образи України XVII-XX ст. з приватної колекції Ольги Богомолець» у Київському Музеї російського мистецтва (1-14 березня 2008 р.)). - К., 2008. - 206 c.

2. Горький М. О формализме [Электронный ресурс]. (Впервые напечатано в газете «Правда», 1936, 9 апреля). - Режим доступа: http:/gorkiy.litinfo.ru/gorkiy/articles/article-86.htm

3. Донских О.А. Происхождение языка как философская проблема. - Новосибирск, 1984. - $126 \mathrm{c.}$

4. Косміна О. Традиційне вбрання українців. - К., 2008. - 160 с.

5. Леви-Строс К. Структура и форма (Размышления над одной работой Владимира Проппа) // Зарубежные исследования по семиотике фольклора; [Мелетинский Е.М., Неклюдов С.Ю. (сост.)]. - М., 1985. - С.9-34.

6. Митрополит Іларіон (Огієнко). Дохристиянські вірування українського народу. - К., 1995. - 424 с.

7. Найден $O$. Народна ікона Середньої Наддніпрянщини в контексті сільського культурного простору. - К., 2009. - 543 с.

Богомолеиь О.В. Семантика народної ікони в контексті методологічних засад структуралізму.

У статті аналізуються методологічні засади дослідження народної ікони. 3 цією метою розглядається правомірність вивчення народної ікони крізь призму методологічних принципів формалізму та підкреслюється іiі підпорядкований характер. Головна увага приділяється світоглядним основам художнього антианатомізму народної ікони, який постає як результат глибоко вкорінених у колективну свідомість міфологічних уявлень українського народу. Підкреслюється, що, незважаючи на позірну різноманітність народних ікон, їх споріднює іманентно присутня у кожній з них міфологічна структура, яка визначає своєрідність не тільки народної ікони, а й української культури в цілому.

Ключові слова: народна ікона, структура, формалізм, стуктуралізм, антианатомічність, зміст, форма, міфологічна свідомість.

Богомолеиь О.В. Семантика народной иконы в контексте методологических приничипов структурализма.

В статье анализируются методологические основания исследования народной иконы. С этой целью рассматривается правомерность изучения народной иконы в контексте методологических принципов формализма и раскрывается ее подчиненный характер. Главное внимание уделяется мировоззренческим основам художественной антианатомичности народной 
иконы; обосновывается, что она возникает как результат глубоко укорененных в коллективное сознание мифологических представлений украинского народа. Подчеркивается, что, несмотря на кажущееся разнообразие народных икон, их роднит имманентно присутствующая в каждой из них мифологическая структура, которая определяет своеобразие не только народной иконы, но и украинской культуры в целом.

Ключевые слова: народная икона, структура, формализм, структурализм, антианатомичность, содержание, форма, мифологическое сознание.

Bohomolets O. Semantics of people's icons in the context of methodological princeples of structuralism.

This article analyzes the methodological basis of the study of folk icons. To that end in view, the legality of folk icon through the prism of the methodological principles of formalism was analyzed and emphasized subordinated nature of folk icon. Emphasis is given to philosophical grounds of antianatomism of folk art icon, which appears the result of deep-rooted in the collective consciousness mythological representations of the Ukrainian people. Along with the specified highlights that despite the apparent brilliance and seeming of folk icons, they are connected by the constantly present in each of them a mythological structure, which determines not only the originality of folk icon, but the Ukrainian culture in general.

Key words: folk icon, structure, formalism, structuralism, antianatomism, content, form, a mythological consciousness. 